\title{
DETERMINATION OF CONSTANT ELASTIC OF PEQUI WOOD USING ULTRASOUND
}

DETERMINAÇÃO DAS CONSTANTES ELÁSTICAS DA MADEIRA PEQUI UTILIZANDO ULTRASSOM

EDGAR VLADIMIRO MANTILLA CARRASCO, Dr. | UFMG

REJANE COSTA ALVES, Dra. | UFES

PAULO GUSTAVO VON KRÜGER, Dr. | UFMG

MARCO ANTONIO PENIDO DE REZENDE, Dr.| UFMG

VINNICIUS DORDENONI PIZZOL, Dr. | UNIBH

JUDY NORKA RODO MANTILLA, Dra. | UFMG

MÔNICA AZEVEDO SMITS DE CAMPOS GUIMARÃES, Dra. | FAMIB-BH

\begin{abstract}
RESUMO
A madeira é um material de construção com elevado nível de sustentabilidade e renovável que captura e retém CO2 durante todo seu ciclo de vida. Devido a esta peculiaridade é importante que o dimensionamento, quando utilizado como material estrutural, seja o mais preciso possível. Assim será possível utilizar este material com maior desempenho. Para isto é necessário conhecer, com maior precisão, as características mecânicas da madeira. Os ensaios mecânicos, devido a ser um material ortotrópico, são difíceis e de elevado custo. É necessário determinar três módulos de elasticidade, três módulos de deformação transversal e seis coeficientes de Poisson. Assim o objetivo deste artigo é determinar as constantes elásticas utilizando o método de propagação de ondas ultrassônicas na madeira Pequi (Caryocar Villosum). O aparelho utilizado foi o Panametrics - NDT EPOCH4, com transdutores de ondas longitudinais e transversais e frequência de $1 \mathrm{MHz}$. Foram utilizados corpos de prova com dimensões de 5x5x15 cm, sendo necessários seis tipos de corpos de prova e sete repetições. Cada corpo de prova foi preparado com a direção necessária das fibras, para determinar as constantes de rigidez. Com a aplicação das equações de Christoffel determinou-se as 12 constantes elásticas. Conclui-se que é possível determinar os valores das constantes elásticas utilizando o método de propagação de ondas ultrassônicas, com boa precisão, de forma rápida e com custo reduzido.
\end{abstract}

PALAVRAS CHAVE: Ensaios não destrutivos;módulo de elasticidade; madeira

\begin{abstract}
Wood is a building material with high level of sustainability and renewable that captures and retains $\mathrm{CO} 2$ throughout its life cycle. Due to this peculiarity, it is important that the design when used as a structural materialbe as accurate as possible. Thus, it will be possible to use this material with greater performance. For this, it is necessary to know, with the highest accuracy, the mechanical characteristics of the wood. Mechanical tests, due to being an orthotropic material, are difficult and expensive. It is necessary to determine three modules of elasticity, three modules of transversal deformation and six Poisson's ratio. So the objective of this paper is to determine the elastic constants using the ultrasonic wave propagation method in Pequi wood (Caryocar Villosum). The device used was the Panametrics - NDT EPOCH4 with longitudinal and shear wave transducers and a frequency of $1 \mathrm{MHz}$. Specimens with dimensions of $5 \times 5 \times 15 \mathrm{~cm}$ were used, requiring six types of specimens and seven repetitions. Each specimen was prepared, with the necessary fiber direction, to determine the stiffness constants. With the application of Christoffel's equations, the 12 elastic constants were determined. It is concluded that it is possible to determine the values of the elastic constants using the ultrasonic wave propagation method, with good precision, fast and with reduced cost.
\end{abstract}

KEY WORDS: Not destructive tests; elasticity module; wood. 


\section{INTRODUCTION}

With the devastation of forests raised the concern about the use of wood properly characterized and methods development and faster analysis, which generate fewer losses. In this context, are introduced non-destructive methods for evaluation of thematerial. The study of wave propagation principle applies to moving orthotropic materials began in 1880 with the development of the Christoffel equation (BUCUR, 1984). In addition, about a century later, initiated studies aimed at physical and mechanical characterization of wood (STANGERLIN et al., 2010). Authors like Bolza and Kloot (1963), Kennedy (1965), Bodig and Godmann (1972), Curry and Tory (1976), Warren (1979), Atherton (1980), Oberhofnerová et al. (2016) and Haseli, et al. (2020) have contributed to the perception of the importance of acoustic wave propagation technique to estimate the properties of the wood.

To the present day, there are differences of opinions regarding the evaluation of the modulus of elasticity of wood through wave propagation. Some authors, such as Steiger (1997), Ross et al. (1998), Gautam and Bartholomeu (2000), and Bjelanović et al. (2019), used the Edin (dynamic modulus of elasticity) of the relationship between the speed of wave propagation and wood density (EQ. Christoffel), doing an approximation of equation, without taking into account the various influences of the Poisson coefficient and of transverse elasticity modules. Other authors such as Bucur (1983), Sandoz (1989), Bartholomeu et al. (2003), Gonçalves et al. (2011) and Haseli et al. (2020) called the Christoffel equation of elastic constant. They claim to be considered like and din is required to be taken into account a number of other factors, such as the Poisson coefficients. The purpose of this study is to estimate the elastic properties of wood with the use of non-destructive method of ultrasonic wave propagation considering orthotropic material.

\section{MATERIALS AND METHODS}

The non-destructive tests were performed in the laboratory of construction materials and structures, Lab END-UNICAMP. Woods tested were in the form of polyhedra (Caryocar villosum), pequi. In all, were used in the six directions, oriented CPs the three major,longitudinal (I), radial (II), tangential (III) and three intermediate, longitudinal - radial (IV), tangential - radial (V), longitudinal - tangential (VI), figure 1. It is worth mentioning that most of the worksin Brazilian woods is carried out only with wood oriented in three main directions. Took care to use seven repetitions in order to determine the characteristic values for the calculation of these properties, these data were not available in the literature.

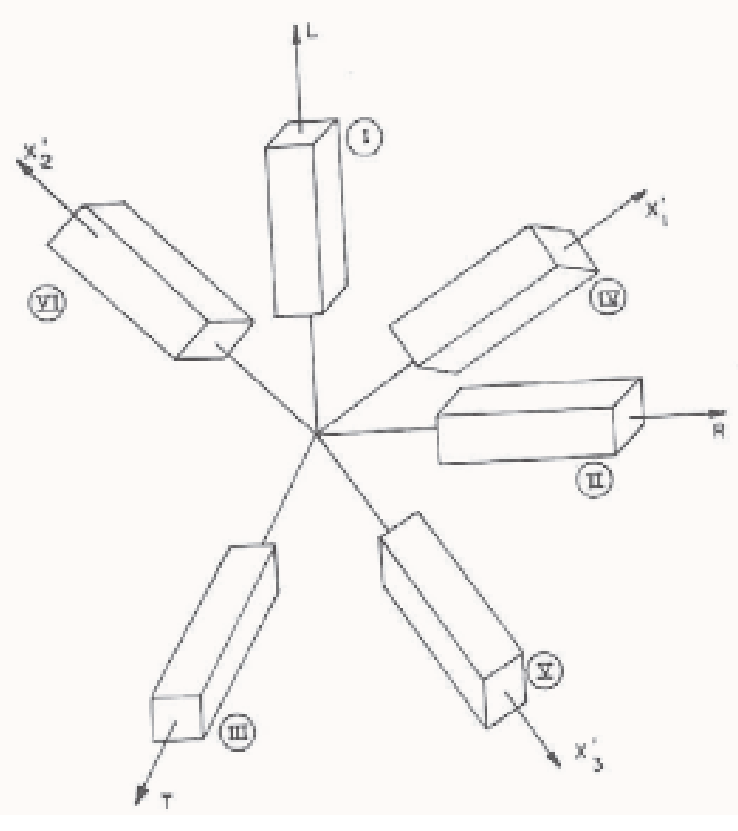

Figure1 - Types of specimens

Fonte: Ballarin e Nogueira (2003)

The device used was the Panametrics-NDT EPOCH4 (Olympus Panametrics NDT/Inc, San Diego, CA), and use of longitudinal and transverse transducers, with frequency of $1 \mathrm{MHz}$.

For each wood pequi were used seven beams of $2.5 \mathrm{~m}$ length and cross section of $150 \times 150 \mathrm{~mm}$. They were air dried and subsequently deployed in smaller pieces. Then were stored for stabilization of humidity, and subsequently made-of-proof bodies (CPs) in accordance with Brazilian standard NBR 7190 (1997), for determination of the moisture content.

\subsection{Wave propagation}

The wave propagation in wood is described by movement equations established for an anisotropic solid, which can be found through a combination of Newton's law and the generalized Hooke's law (Bucur (1984), Carrasco and Azevedo Junior (2003), Equation (1).

$$
\rho \ddot{u}_{i}=C_{i k l m} \frac{\partial}{\partial x_{k}}\left(\frac{\partial u_{m}}{\partial x_{1}}\right)
$$

Assuming that plane harmonic waves are spreading in the material, the solution of Equation (3) is the Equation (2).

$$
\left(\rho \omega^{2} \delta_{i m}-C_{i k l m} k_{k} k_{l}\right) u_{m}=0
$$

Where $\mathrm{u}_{\mathrm{oi}}$ are the amplitudes of the components of the displacement vector and $k_{j}$ are the components of the wave vector. The value $u_{0 i}$ can be written as $u_{\text {oai }}$ where 
$\mathrm{u}_{0}$ is the amplitude of the displacement and $\mathrm{a}_{\mathrm{i}}$ are the direction cosines of the displacement vector of the particle.

Substituting the value expressed by Equation (2) into Equation (1) yields to Equation (3). This equation can be written in a more homogeneous by making $u_{i}=u_{m \delta i m^{\prime}}$ where the tensor $\delta_{i m}$ is the unit tensor or Kronecker delta, Equation (4).

$$
\begin{aligned}
& \rho \omega^{2} u_{i}=C_{i k l m} k_{k} k_{l} u_{m} \\
& \left(\rho \omega^{2} \delta_{i m}-C_{i k l m} k_{k} k_{l}\right) u_{m}=0
\end{aligned}
$$

Equation (4) developed by Christoffel (Bucur, 1984) is commonly known as Christoffel's equation. It represents a set of three homogeneous equations of first degree (linear) in u1, u2 and u3. These equations have nonzero, not trivial solutions if, and only if, the determinant of coefficient matrix is equal to zero, Equation (5).

The development of this equation provides a cubic equation in $\omega^{2}$ (or in terms of $v^{2}$ ). The three roots of the equation are different, generating three different values of propagation velocities.

$$
\left|C_{i k l m} k_{k} k_{l}-\rho \omega^{2} \delta_{i m}\right|=0
$$

In general, it is more convenient to write Equation (4) in the form of Equation (6), where in tensor $\lambda_{\text {im }}$, known as Christoffel's tensor, defined in Equation (7).

$$
\begin{aligned}
& \left(\lambda_{i m}-\rho v^{2} \delta_{i m}\right) u_{m}=0 \\
& {\left[\begin{array}{ccc}
\lambda_{11}-\rho v^{2} & \lambda_{12} & \lambda_{13} \\
\lambda_{21} & \lambda_{22}-\rho v^{2} & \lambda_{23} \\
\lambda_{31} & \lambda_{32} & \lambda_{33}-\rho v^{2}
\end{array}\right]\left[\begin{array}{l}
u_{1} \\
u_{2} \\
u_{3}
\end{array}\right]=0} \\
& \lambda_{i m}=C_{i k l m} n_{k} n_{1}
\end{aligned}
$$

In Equation (6), $v$ represents the phase velocity of the waves and $\mathrm{n}_{\mathrm{i}}$, implicit in $\lambda_{\mathrm{im}}$, denote the direction cosines of the normal of the wavefronts. Thus, the new factor must be calculated by Equation (7). The tensor $\lambda_{\text {im }}$ depends on the structural symmetry of the material and direction of this wave in this material. Therefore, Equation (7) can be rewritten in the matrix format, Equation (8).

$$
\begin{aligned}
& \left|\lambda_{\mathrm{im}}-\rho \mathrm{v}^{2} \delta_{\mathrm{im}}\right|=0 \\
& {\left[\begin{array}{ccc}
\left(\lambda_{11}-\rho v^{2}\right) & \lambda_{12} & \lambda_{13} \\
\lambda_{12} & \left(\lambda_{22}-\rho v^{2}\right) & \lambda_{23} \\
\lambda_{13} & \lambda_{32} & \left(\lambda_{33}-\rho v^{2}\right)
\end{array}\right]=0}
\end{aligned}
$$

It is often convenient to use matrix notation instead of tensor notation. For this, the following scheme is adopted: 11-(1), 22-(2), 33-(3),23-(4), 13-(5), 12-(6).
Thus, expanding the equation (7) and using the symmetry of the tensor $C_{\mathrm{ik} / m^{\prime}}$ Equations (10) are obtained.

$\lambda_{1}=C_{11} n_{1}^{2}+C_{66} n_{2}^{2}+C_{55} n_{3}^{2}+2 C_{16} n_{1} n_{2}+2 C_{15} n_{1} n_{3}+2 C_{56} n_{2} n_{3}$

$\lambda_{2}=C_{66} n_{1}^{2}+C_{22} n_{2}^{2}+C_{44} n_{3}^{2}+2 C_{26} n_{1} n_{2}+2 C_{46} n_{1} n_{3}+2 C_{24} n_{2} n_{3}$

$\lambda_{3}=C_{55} n_{1}^{2}+C_{44} n_{2}^{2}+C_{33} n_{3}^{2}+2 C_{45} n_{1} n_{2}+2 C_{35} n_{1} n_{3}+2 C_{34} n_{2} n_{3}$

$\lambda_{4}=C_{65} n_{1}^{2}+C_{24} n_{2}^{2}+C_{43} n_{3}^{2}+C_{64} n_{1} n_{2}+C_{63} n_{1} n_{3}+C_{25} n_{2} n_{1}+C_{23}$ $\mathrm{n}_{2} \mathrm{n}_{3}+\mathrm{C}_{45} \mathrm{n}_{3} \mathrm{n}_{1}+\mathrm{C}_{44} \mathrm{n}_{3} \mathrm{n}_{2}$

$\lambda_{5}=C_{15} n_{1}^{2}+C_{64} n^{2}+C_{53} n_{3}^{2}+C_{14} n_{1} n_{2}+C_{15} n_{1} n_{3}+C_{65} n_{2} n_{1}+C_{63}$ $\mathrm{n}_{2} \mathrm{n}_{3}+\mathrm{C}_{55} \mathrm{n}_{3} \mathrm{n}_{1}+\mathrm{C}_{54} \mathrm{n}_{3} \mathrm{n}_{2}$

$\lambda_{6}=C_{15} n_{1}^{2}+C_{62} n^{2}+C_{54} n_{3}^{2}+C_{12} n_{1} n_{2}+C_{14} n_{1} n_{3}+C_{66} n_{2} n_{1}+C_{64}$ $\mathrm{n}_{2} \mathrm{n}_{3}+\mathrm{C}_{56} \mathrm{n}_{3} \mathrm{n}_{1}+\mathrm{C}_{52} \mathrm{n}_{3} \mathrm{n}_{2}$

A careful examination of Equation (9) shows that the displacement vectors (eigenvectors) associated with each eigenvalue, $\rho v^{2}$, are mutually perpendicular. For a given direction of propagation, defined by the wave vector $\overrightarrow{\mathrm{k}}$, three waves propagate with displacement vectors mutually perpendicular to each other and with different velocities. In general, these waves are not purely longitudinal or purely transverse.

However, for certain directions of propagation in a given medium material, in which $\overrightarrow{\mathrm{k}}$ is an eigenvector of $\lambda_{\mathrm{im}}{ }^{\prime}$ a wave is strictly longitudinal and the other two are purely transverse. For a pure longitudinal wave the displacement vector of the particle $\vec{u}$ is parallel to the unit vector perpendicular to the wave fronts $\vec{n}$. Therefore, the vectorial product $\overrightarrow{\mathrm{u}} \times \vec{n}$ is zero. On the other hand for a pure transverse wave, the same vectors are perpendicular to each other and, consequently, the scalar product $\vec{u} \cdot \vec{n}$ is zero.

Christoffel has demonstrated that the direction cosines $a_{i}$ of the displacement of the particles of the wave fronts are connected with the corresponding wave velocities, Equation (11).

$$
\begin{aligned}
& a_{1} \lambda_{11}+a_{2} \lambda_{12}+a_{3} \lambda_{13}=a_{1} \rho v^{2} \\
& a_{1} \lambda_{12}+a_{2} \lambda_{22}+a_{3} \lambda_{23}=a_{2} \rho v^{2} \\
& a_{1} \lambda_{13}+a_{2} \lambda_{23}+a_{3} \lambda_{33}=a_{3} \rho v^{2}
\end{aligned}
$$

This set of equations can be easily deduced from Equation (6), replacing $u_{m}$ for the direction cosines $a_{i}$ of the particle $\overrightarrow{\mathrm{u}}$ displacement vector, Equation (12). Thus, the known propagation velocity of the wave propagation direction and density of the wood the elements of the matrix elastic constants can be determined. 


$$
\begin{aligned}
& \lambda_{m i} a_{i}-\rho v^{2} \delta_{m i} a_{i}=0 \quad \therefore \\
& \lambda_{m i} a_{i}=\rho v^{2} \delta_{m i} a_{i}
\end{aligned}
$$

The determination of elastic constants of wood can be simplified when considering it, as a first approximation, as a solid orthogonally isotropic or simply orthotropic. The matrix of elastic coefficients of an orthotropic solid is given by equation (13). Thus, it is possible to distinguish, in a wooden piece, three structural planes of symmetry that are both elastic planes of symmetry, as illustrated in figure 1 .

$$
[C]_{\text {Orthotropic }}=\left[\begin{array}{cccccc}
c_{11} & c_{12} & c_{13} & 0 & 0 & 0 \\
c_{12} & c_{22} & c_{23} & 0 & 0 & 0 \\
c_{13} & c_{13} & c_{33} & 0 & 0 & 0 \\
0 & 0 & 0 & c_{44} & 0 & 0 \\
0 & 0 & 0 & 0 & c_{55} & 0 \\
0 & 0 & 0 & 0 & 0 & c_{66}
\end{array}\right]
$$

With the velocity of wave propagation in the ultrasonic tests and wood apparent density, using Christoffel's equation, the wood stiffness constant values were estimated to be approximately the dynamic moduli of elasticity. This equation (14) used by Gonçalves and Bartholomeu (2000) and Bucur (2006), obtained good results.

$$
c=\frac{\rho V^{2}}{g}
$$

Where: $\mathrm{C}=$ stiffness constant, $\mathrm{MPa}$; $\mathrm{V}=$ velocity of wave propagation, $\mathrm{m} . \mathrm{s}^{-1} ; \rho=$ wood apparent density, at $12 \%$ moisture content, $\mathrm{kg} \cdot \mathrm{m}^{-3}$ and $\mathrm{g}=$ acceleration of gravity, $10 \mathrm{~m} \cdot \mathrm{s}^{-2}$.

\section{RESULTS AND CONSIDERATIONS}

In the table 1 is presented the numerical values of speed of propagation of the wave and their respective constant elastics (CE). It is worth emphasizing that, the direction 1 refers to the longitudinal direction, the 2 to the radial one, and the 3 to the tangential one (BUCUR, 2006).

\begin{tabular}{|l|l|l|l|l|}
\hline CE & N & Average & S.D. & $95 \%$ Cl \\
\hline C11 & 7 & 14612 & 1864 & $(12888 ; 16336)$ \\
\hline C22 & 7 & 3555 & 544 & $(3052 ; 4058)$ \\
\hline C33 & 7 & 2413 & 511 & $(1940 ; 2886)$ \\
\hline C44 & 7 & 800 & 48 & $(754 ; 844)$ \\
\hline C55 & 7 & 1087 & 109 & $(986 ; 1187)$ \\
\hline C66 & 7 & 1355 & 124 & $(1240 ; 1470)$ \\
\hline C12 & 7 & 14612 & 1864 & $(12888 ; 16336)$ \\
\hline C13 & 7 & 3555 & 544 & $(3052 ; 4058)$ \\
\hline C23 & 7 & 2413 & 511 & $(1940 ; 2886)$ \\
\hline
\end{tabular}

Table 1 - Average speeds of ultrasonic waves in the specimens Fonte: prepared by the author

Bucur (2006) affirms, that to attend the basic theory, the value must be $\mathrm{C} 11>\mathrm{C} 22>\mathrm{C} 33, \mathrm{C} 44<\mathrm{C} 55<\mathrm{C} 66$ and $\mathrm{C} 12>\mathrm{C} 13>\mathrm{C} 23$, and the same took place for all the rehearsed samples.

In the table 2 there are presented the appreciated values of each one of constant elastics, it is noticed that the biggest values of coefficient of variation were for the Poisson's, which variation was from 32.64 to $47.16 \%$. Bucur (2006) affirms that this phenomenon was already expected, because of being treated as a heterogeneous material.

\begin{tabular}{|l|l|l|l|l|l|l|l|l|l|l|l|l|}
\hline & $\mathrm{E}_{\mathrm{L}}$ & $\mathrm{E}_{\mathrm{R}}$ & $\mathrm{E}_{\mathrm{T}}$ & $\mathrm{G}_{\mathrm{TR}}$ & $\mathrm{G}_{\mathrm{TL}}$ & $\mathrm{G}_{\mathrm{LR}}$ & $\mathrm{V}_{\mathrm{RL}}$ & $\mathrm{V}_{\mathrm{TL}}$ & $\mathrm{V}_{\mathrm{LR}}$ & $\mathrm{V}_{\mathrm{TR}}$ & $\mathrm{V}_{\mathrm{LT}}$ & $\mathrm{V}_{\mathrm{RT}}$ \\
\hline Average & 11561 & 2315 & 1598 & 800 & 1087 & 1355 & 0.12 & 0.09 & 0.58 & 0.36 & 0.59 & 0.53 \\
\hline Standard Deviation & 2413 & 406 & 333 & 48 & 109 & 124 & 0.05 & 0.04 & 0.19 & 0.13 & 0.22 & 0.19 \\
\hline Variation Coefficient & 20.87 & 17.53 & 20.82 & 6.06 & 10.03 & 9.17 & 44.34 & 47.16 & 32.64 & 35.57 & 37.51 & 36.51 \\
\hline
\end{tabular}

Table 2 - Average values of the elastic constants.

Fonte: prepared by the author

In the Figure 2 is shown the relation between the static values and the appreciated ones by the non-destructive method of ultrasonic wave's propagation, for the 3 directions ( $\mathrm{L}, \mathrm{T}$ and $\mathrm{R})$.

\section{CONCLUSIONS}

It is possible to determine the values of the elastic constants using ultrasonic wave propagation. The theory C11> C22> $\mathrm{C} 33, \mathrm{C} 44<\mathrm{C} 55<\mathrm{C} 66$ and $\mathrm{C} 12>\mathrm{C} 13>\mathrm{C} 23$ was attended.

It is possible to estimate with precision the value of Estatic based on the propagation of ultrasonic waves.

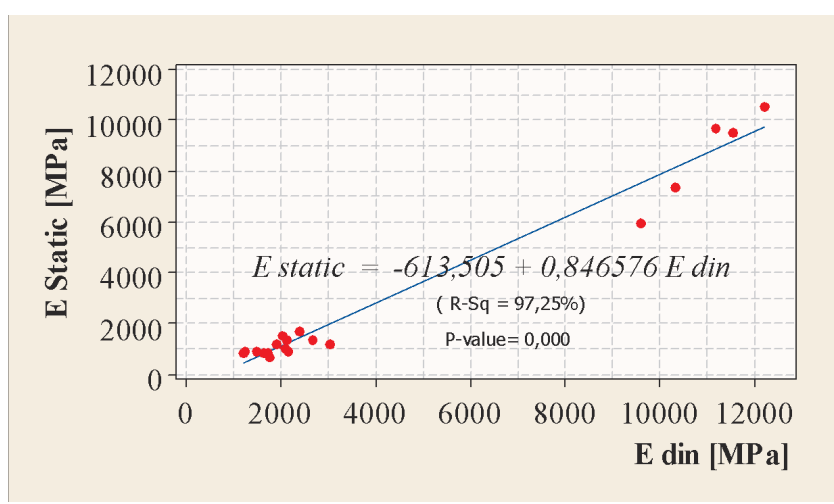

Figure 02 - Static vs. dynamic longitudinal elasticity module (EL, ET, and ER) Fonte: prepared by the author 


\section{ACKNOWLEDGEMENTS}

National Counsel of Technological and Scientific Development (CNPq) and Foundation for Research Support of the State of Minas Gerais (FAPEMIG), for the financial support given to this research., for the financial support given towards this research project.

\section{REFERENCES}

ASSOCIAÇÃO BRASILEIRA DE NORMAS TÉCNICAS ABNT. NBR 7190;"Projeto de estruturas de madeira". Rio de Janeiro, 1997.

ATHERTON,G.H.;"Preliminary study of proportional limit as a predictor of ultimate strength in bending". Forest. Prod. J. v. 30, n. 1, p. 47-53, 1980.

BALLARIN, A.W.; NOGUEIRA, M.; "Caracterização elástica da madeira de Eucalyptus citriodora" CERNE, v. 09, n.1, p. 69-83, 2003.

BJELANOVIĆ, A.; FRANKOVIĆ, T.; GRANDIĆ, I.Š; "Adjustments of dynamic MOE on referent moisture content of wood and temperature in grading of small-sized samples" Građevinar, v.71, n.2, p. 125-135, 2019

BODIG J.; GODMANN, J.R.;"Prediction of elastic parameters for Wood" Wood Sci. v. 5, p. 249-264,1972. BOLZA, E.; KLOOT, N.M.;"The mechanical properties of 174 Australian timbers" Div. For. Prod. CSIRO Melbourne Tech. Paper. n. 2, 1963.

BUCUR, V.;"An ultrasonic method for measuring the elastic constants of wood increment cores bored from living trees" Ultrasonics, v. 21, p. 116-126, 1983. BUCUR, V.;"Acoustics of Wood", 2. ed. new York, CRC press, v. 1,399 p., 2006.

BUCUR, V.;"Elastic constants for wood by an ultrasonic method" Wood Sci. Technol. v.18, p. 255-265, 1984.

CARRASCO, E.V.M.; AZEVEDO JÚNIOR, A.P.;"Avaliação não-destrutiva de propriedades mecânicas de madeiras através de ultra-som - fundamentos físicos e resultados experimentais" Engenharia Civil, v. 1, n. 16, p. 27-37,2003.

CURRY, W.T.; TORY, J.R.;"The relation between the modulus of rupture and modulus of plasticity of timber". Aylesbury, Bucks Building Research Establishment, Princess Risboriough Laboratory, Current paper. n. 30. 1976.

GONÇALVES, R.; BARTHOLOMEU, A.; "Avaliação do desempenho de ensaio não destrutivo em vigas de madeira de Eucalyptus citriodora e Pinus elliottii" Revista Brasileira de Engenharia Agrícola e Ambiental, v.4, n.2, p.269-274, 2000.

GONÇALVES, R.; TRINCA, A.J.; CERRI, D.G.P.;"Comparison of elastic constants of wood determined by ultrasonic wave propagation and static compression testing" Wood and Fiber Science, v. 43, n. 1, p. 64-75, 2011.

HASELI, M.; LAYEGHI, M.; HOSSEINABADI, $H . Z$.;"Evaluation of modulus of elasticity of date palm sandwich panels using ultrasonic wave velocity and experimental models" Measurement, v. 149, n. 107016, p. 1-9, 2020.

KENNEDY, E.I.;"Strength and related properties of wood grown in Canada". Dept. of Forestry Puplications. n. 1104, Ottawa. 1965.

OBERHOFNEROVÁ, E.; ARNETOVÁ, K.; HOLEČEK, T.; BORU゚VKA, V.; BOMBA, J.; "Determination of Correlation between Destructive and Nondestructive Test Methods Applied on Modified Wood Exposed to Natural Weathering" BioResources, v. 11. n. 2, p. 5155-5168, 2016.

ROSS, R.J.; BRASHAW, B.K.; PELLERIN, R.F.;"Nondestructive evaluation of Wood" Forest Products Journal, v. 48, n. 1, p. 14-19, 1998.

SANDOZ, J.L.; "Triage et fiabilité de bois de construction". 186f. Tese (Doutorado em Sciences Techiniques) - Departamento de Génie Civil, Ecole Polytechnique Federale dee Lausanne, Lausanne, Suisse.1989.

STANGERLIN, D.M.; GONÇALEZ, J.C.; GONÇALVES, R.; SANTINI, E.J.; CALEGARI, L.; MELO, R.R.; GATTO, D.A.; "Avaliação de tipos de ondas geradas por dois modelos de transdutores para determinação do módulo de elasticidade dinâmico" Floresta, v. 40, n. 4, p. 691-700, out.-dez. 2010.

STEIGER, R.;"Sortierung von Rund-und Schnittholz mittels Ultraschall" Holzforschung und Holzverwertung, v. 49, n. 2, p. 28-35, 1997.

WARREN, W.G.;"A critical examination of the statistical techniques available for estimating exclusion limits from in-grade tests". Technical Rapport, Western Forest Prod. Lab., Vancouver, B. C. 1979. 


\section{AUTORES}

ORCID: 0000-0001-7870-0283

EDGAR VLADIMIRO MANTILLA CARRASCO, Dr. | Universidade Federal de Minas Gerais, Escola de Arquitetura, Belo Horizonte, MG, Brasil. | Correspondência para: R. Paraíba, 697 - Funcionários, Belo Horizonte - MG, 30130-140. | E-mail:mantilla.carrasco@gmail.com

ORCID: 0000-0003-4059-3974

REJANE COSTA ALVES, Dra. | Universidade Federal de Espírito Santo, Engenharia Industrial Madeireira, Jerônimo Monteiro, ES, Brasil. | Correspondência para: Av. Gov. Lindemberg, no 316 - Centro, Jerônimo Monteiro - ES, 29550-000 | E-mail: rejanealves.ufes@gmail.com

ORCID: 0000-0003-3628-911X

PAULO GUSTAVO VON KRÜGER, Dr. | Universidade Federal de Minas Gerais, Escola de Arquitetura, Curso de Design, Belo Horizonte, MG, Brasil. | Correspondência para: R. Paraíba, 697 - Funcionários, Belo Horizonte - MG, 30130-140. | E-mail: paulovonkruger@gmail.com

ORCID: 0000-0001-7896-8669

MARCO ANTÔNIO PENIDO DE REZENDE, Dr. | Universidade Federal de Minas Gerais, Escola de Arquitetura, Belo Horizonte, MG, Brasil. | Correspondência para: R. Paraíba, 697 Funcionários, Belo Horizonte - MG, 30130-140. | e-mail: marco.penido.rezende@hotmail.com

ORCID: 0000-0002-2979-3046

VINNICIUS DORDENONI PIZZOL, Dr.| Centro Universitário de Belo Horizonte - UNIBH, Engenharia Civil, Belo Horizonte, MG, Brasil. | Correspondência para: Rua dos Goitacazes, N³65, Apto 603, Centro, Belo Horizonte- MG CEP 30190-050. | E-mail: vinnicius.pizzol@prof.unibh.br

ORCID: 0000-0001-7426-0970

JUDY NORKA RODO MANTILLA, Dra. | Universidade Federal de Minas Gerais, Escola de Engenharia, Belo Horizonte, MG, Brasil. | Correspondência para: R. Ouro Preto, 1240/1201 - Santo Agostinho, Belo Horizonte - MG, 30170-048. | E-mail:judynorka@gmail.com

ORCID: 0000-0002-7672-6428

MÔNICA AZEVEDO SMITS DE CAMPOS GUIMARÃES, Dra. | Centro Universitário Metodista Izabela Hendrix FAMIH, Curso de Arquitetura, Belo Horizonte, MG, Brasil.| Correspondência para: R. Espírito Santo, 1100/1501 - Centro, Belo Horizonte - MG, 30160-031.| E-mail: azevedosmits@gmail.com

\section{COMO CITAR ESTE ARTIGO}

CARRASCO, Edgar Vladimiro Mantilla; ALVES, Rejane Costa; VON KRÜGER, Paulo Gustavo; REZENDE, Marco Antônio Penido de; PIZZOL, Vinnicius Dordenoni; MANTILLA, Judy Norka Rodo; GUIMARÃES, Mônica Azevedo Smits de Campos. Determination Of Constant Elastic Of Pequi Wood Using Ultrasound. MIX Sustentável, [S.I.], v. 6, n. 4, p. 139-144, ago. 2020. ISSN 24473073. Disponível em:<http://www. nexos.ufsc.br/index.php/mixsustentavel>. Acesso em: dia mês. ano. doi:https://doi.org/10.29183/2447-3073. MIX2020.v6.n4.139-144.

DATA DE ENVIO: $12 / 05 / 2020$

DATA DE ACEITE: $28 / 07 / 2020$ 